\title{
The Performance of the Pharmacist in Forensic Toxicology and its Importance: Literature Review
}

Jaqueline da Costa Lima ${ }^{1}$, Andrezza Fabianni Pedrosa dos Santos Lima ${ }^{2}$, Emilly Tainá Batista da Silva $^{3}$, Emivaldo Batista da Silva ${ }^{4 *}$, Joana Bulhões Alvares da Silva Lima ${ }^{5}$, Maria Caroline da Silva ${ }^{6}$, Maria Elisângela de França Silva ${ }^{7}$, Bruna Carneiro de Siqueira Santiago ${ }^{8}$, Thacyla Emanuely Santos Alves $^{9}$, Luciana Pereira Damacena ${ }^{10}$, Daniele Barros Muniz ${ }^{11}$, Edson André Batista ${ }^{12}$, Átala Dandara Gomes ${ }^{13}$,Elymax Miquéias Lima Teodósio dos Santos ${ }^{14}$, Cláudio Junyo dos Santos ${ }^{15}$, Maria Isabela Silva Paiva ${ }^{16}$, Emanuella Barros de Souza Oliveira Alvares ${ }^{17}$

1,4,5,6,7,8,10,11,12,13,14,15,16 Department of Pharmaceutical Sciences, University Center of Vitória de Santo Antão - (UNIVISA) Vitória de Santo Antão, Brazil.

2,9 Department of Nutrition, University Center of Vitória de Santo Antão - (UNIVISA), Vitoria de Santo Antão, Brazil

3 Department of Biomedicine, Post-Graduation in Laboratory Clinical Microbiology (ASCES- UNITA) Caruaru - PE

17 Department of Biology, Center for Biological Sciences, Professor of the Degree Course in Biology, University Center of Vitória de Santo Antão (UNIVISA), Vitória de Santo Antão, Brazil

E-mail adresses: jaqueline.2017186063@gmail.com1 (Jaqueline da Costa Lima), andrezzafpslima@hotmail.com2 (Andrezza Fabianni Pedrosa dos Santos Lima), emilly.taina@hotmail.com3 (Emilly Tainá Batista da Silva), emivaldobatista4@gmail.com4 (Emivaldo Batista da Silva),joanafarmacia2018@gmail.com5 (Joana Bulhões Alvares da Silva Lima), maria.201819008@univisa.edu.br6 (Maria Caroline da Silva), maria2018286014@univisa.edu.br7 (Maria Elisângela de França Silva), brunasiqueira1@hotmail.com8 (Bruna Carneiro de Siqueira Santiago), thacylasantos2020@gmail.com9 (Thacyla Emanuely Santos Alves), Luciana.2019186017@univisa.edu.br10 (Luciana Pereira Damacena), daniele.201924000@univisa.edu.br11 (Daniele Barros Muniz), edsonandre.pe@gmail.com12 (Edson André Batista), atala.201924050@univisa.edu.br13 (Átala Dandara Gomes), elymaxmiqueias19@gmail.com14(Elymax Miquéias Lima Teodosio dos Santos) emanuella.barros@hotmail.com15 (Emanuella Barros de Souza Oliveira Alvares).

${ }^{*}$ Corresponding author

\section{To cite this article:}

Lima, J.C.; Lima, A.F.P.S.; Silva, E.T.B.; Silva, E.B.; Lima, J.B.A.S.; Silva, M.C.; Silva, M.E.F.; Santiago, B.C.S.; Alves, T.E.S.; Damacena, L.P.; Muniz, D.B.; Batista, E.A.; Gomes, A.D.; Santos, E.M.L.T.; Santos, C.J.; Paiva, M.I.S.; Álvares, E.B.S.O. The Performance of the Pharmacist in Forensic Toxicology and its Importance: Literature Review. International Journal of Sciences. Vol. 3, No. 1, 2022 , pp.51-54. ISSN 2763-5392.

Received: 11 24, 2021; Accepted: 12 26, 2021; Published: 01 15, 2022

\begin{abstract}
Forensic toxicology is an important tool in the materialization of crime since it is verified the presence of toxic substances that will influence the elucidation of events related to the facts investigated, such as the performance of individuals who were involved in a traffic accident, or substances that have been the cause of death. This is a bibliographic review study, that is, a survey of theoretical framework from scientific publications, this at national and international level involving the performance of the pharmacist in forensic toxicology and its importance the data collection occurred through the Coordination for the Improvement of Higher Education Personnel (CAPES) and Google Scholar. It is understood, therefore, that professionals of the forensic sciences should have continuous training, as well as guidance and ethical and legal training focused on the dilemmas and specific cases of their functions seeking to prevent biases and biases.
\end{abstract}

Keywords: Pharmaceutical Sciences. Forensic toxicology. Harmful toxics.

\section{Introduction}

Forensic Toxicology is an interdisciplinary science capable of detecting toxic agents harmful to the body, assisting in cases of investigation, because it seeks truth before the Law. Being able to detect, quantify, interpret toxic agents found in cases of chain of custody occurrence (AZEVEDO, 2008).

In relation to definition, forensic toxicology is defined as 
the application of toxicology for law purposes, this definition is indeed quite broad, and the most common application of forensic toxicology is the identification of substances that could be involved in death or harm to the health of individuals the property and the environment. (NORONHA, 2013, p. 21).

Xenobiotic poisoning occurs due to their exposure, and may present some signs and symptoms, but are not sufficient to determine the causative agent, it is necessary to perform an initial care, as well as the performance of the examination to detect this causative agent. The determination of the method to be used will depend on the availability of the sample and the type of poses (BRASIL 2019).

Forensic toxicology is an important tool in the materialization of crime since it is verified the presence of toxic substances that will influence the elucidation of events related to the facts investigated, such as the performance of individuals who were involved in a traffic accident, orsubstances that have been the cause of death (Carneiro, RCML 2020, p. 02).

Forensic Toxicology in the Judiciary is of great importance, contributing with analytical techniques for the identification of toxic substances in which it assists in the direction of an investigation, such as death from poisoning or traffic accident. Matrices are used which your choice is determined taking into account the type of sample and exposure.

The choice of the theme proposed a differentiated look at Forensic Toxicology because this area of activity contributes with analytical techniques to assist in the identification of toxic substances and also assists in the direction of an investigation. This literature review had the objectivity to present the role of the pharmacist in forensic toxicology and its importance.

\section{Methodology}

This is a bibliographic review study, that is, a survey of theoretical framework from scientific publications, which is national ly and internationally involving the pharmacist's role in forensic toxicology and its importance.

The data collection occurred through the Coordination for the Improvement of Higher Education Personnel (CAPES) and Google Academic.

The research began in April 2020 by the inclusion criteria: works in English and Portuguese, published in the last five years, which deal with topics related to the pharmacist's performance in forensic toxicology. These, available for free online. Exclusion criteria include: works whose text is not available in full, duplicated, review, meta-analysis, and also works that, after reading, were not related to the research objective.

Regarding the data appreciation, this was performed qualitatively, prioritizing the analysis of micro processes, understanding, interpreting and dialing these findings, interrelating them, through the established criteria.

Therefore, all rules related to ethics and copyright were obeyed, since as a result of the bibliographic characteristic of this study, it was not necessary to evaluate by the Research Ethics Committee.

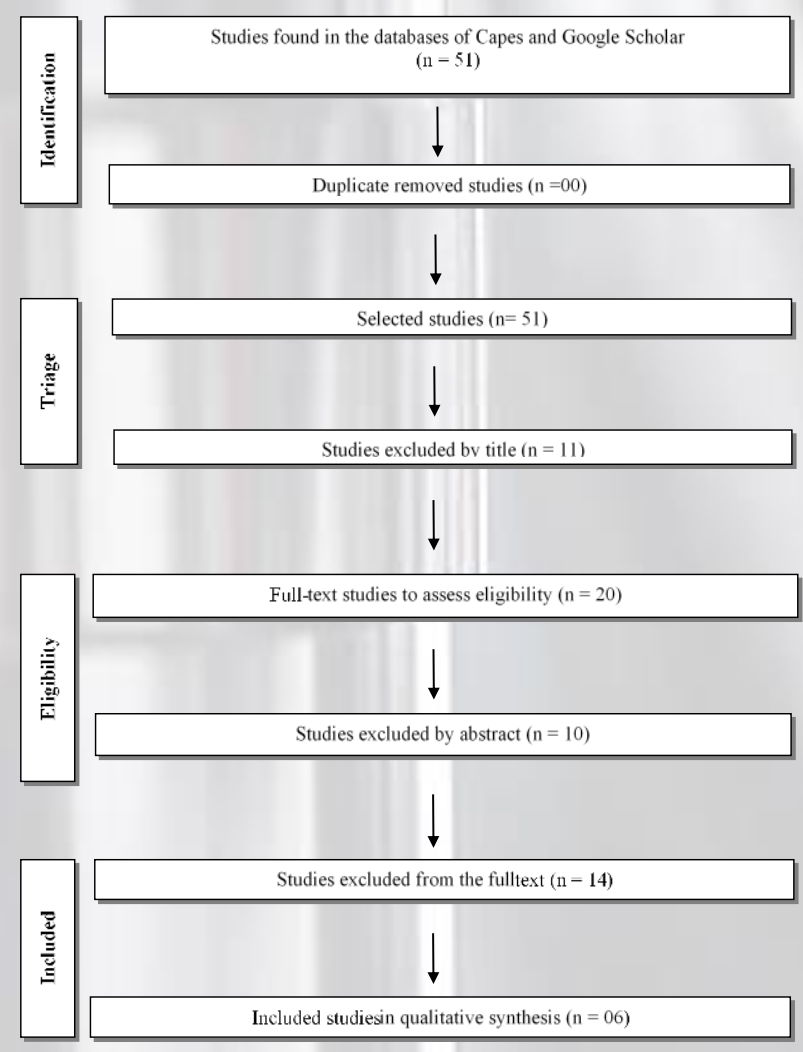

Figure 1. Flowchart of selection criteria and inclusion of studies.

\section{Results and Discussion}

Regarding the results found, a total of 51 works were analyzed, but only 07 works were included in the research, respecting the inclusion criteria.

Forensic toxicology is a multidisciplinary area and its main objective is to support criminal investigation. It is also important to understand the aspects that make up a Toxicological Analysis Report, to correlate it, in case of deaths, with the cause of death of an individual. The Toxicological Expertise Report, together with the Autopsy Report, is important tools in identifying the intoxication or death of a particular individual (BARROS 2021).

It is also worth mentioning that, as in every process that involves analysis of biological material, forensic analysis requires strict quality control, both in the identification of the whole process, as in the analysis itself, following standards for each procedure to be performed.

Toxicology is a science of great importance to society. Although it is not exclusive to the pharmacist, he can work in several areas of this science, because he is able to perform the functions that are required (SERRA 2021). 


\begin{tabular}{|c|c|c|c|c|c|}
\hline Date & Title & Authors & Journals & Goals & Findings \\
\hline 2021 & $\begin{array}{l}\text { Forensic } \\
\text { Sciences } \\
: \text { Ethical } \\
\text { Principle } \\
\mathrm{s} \quad \text { and } \\
\text { Vieses }\end{array}$ & $\begin{array}{l}\text { SERRA, } \\
\text { M.C; } \\
\text { FERNAND } \\
\text { ES, C, M, S. } \\
\text { BARROS, } \\
\text { F; } \\
\text { KUHNEN, } \\
\text { B }\end{array}$ & $\begin{array}{l}\text { Bioethics } \\
\text { Journal }\end{array}$ & $\begin{array}{l}\text { To highlight } \\
\text { the } \\
\text { interdisciplina } \\
\text { rity of the field } \\
\text { engenders } \\
\text { several } \\
\text { methodologie } \\
\text { s for the } \\
\text { execution of } \\
\text { the } \\
\text { expertexams }\end{array}$ & $\begin{array}{l}\text { It was } \\
\text { observed } \\
\text { that law is a } \\
\text { usual tool } \\
\text { in the } \\
\text { forensic } \\
\text { field } 8 . \\
\text { Neverthele } \\
\text { ss, science } \\
\text { and law } \\
\text { obtain } \\
\text { information } \\
\text { and results } \\
\text { in different } \\
\text { ways. }\end{array}$ \\
\hline 2021 & $\begin{array}{l}\text { Forensic } \\
\text { Sciences } \\
: \text { Ethical } \\
\text { principle } \\
\mathrm{s} \quad \text { and } \\
\text { vieses. }\end{array}$ & $\begin{array}{l}\text { BARROS, } \\
\text { F; } \\
\text { KUHNEN, } \\
\text { B; SERRA, } \\
\text { M.C; } \\
\text { FERNAND } \\
\text { ES, C, M, S. }\end{array}$ & $\begin{array}{l}\text { Bioethics } \\
\text { Journal }\end{array}$ & $\begin{array}{l}\text { Evidence that } \\
\text { forensic } \\
\text { sciences } \\
\text { employ } \\
\text { diverse } \\
\text { scientific and } \\
\text { technical } \\
\text { knowledge to } \\
\text { investigate } \\
\text { crimes and } \\
\text { other subjects. }\end{array}$ & $\begin{array}{l}\text { It was } \\
\text { found that } \\
\text { the advance } \\
\text { of the } \\
\text { technology } \\
\text { of certain } \\
\text { crimes and } \\
\text { consequent } \\
\text { ly the } \\
\text { practice of } \\
\text { forensics } \\
\text { became } \\
\text { more } \\
\text { complex. }\end{array}$ \\
\hline 2020 & $\begin{array}{l}\text { Criminal } \\
\text { istics and } \\
\text { Legal } \\
\text { Medicin } \\
\text { e }\end{array}$ & Ram R. & $\begin{array}{l}\text { CML } \\
\text { Magazine }\end{array}$ & $\begin{array}{l}\text { To highlight } \\
\text { the walk that } \\
\text { there were } \\
\text { some } \\
\text { milestones } \\
\text { that } \\
\text { transformed } \\
\text { the reality of } \\
\text { national } \\
\text { forensic } \\
\text { genetics. }\end{array}$ & $\begin{array}{l}\text { It was } \\
\text { observed } \\
\text { that in the } \\
\text { growth } \\
\text { flow of } \\
\text { RIBPG in } \\
\text { other areas } \\
\text { of expertise } \\
\text { have been } \\
\text { developing, } \\
\text { in addition } \\
\text { to forensic } \\
\text { genetics. }\end{array}$ \\
\hline 2019 & $\begin{array}{l}\text { Law of } \\
\text { Article } \\
158 \text { of } \\
\text { Decree } \\
\text { Law No. } \\
3,689 \text { of } \\
\text { October } \\
3,1941 \text {. }\end{array}$ & BRAZIL & Jus Brazil & $\begin{array}{l}\text { To highlight } \\
\text { the law of } \\
\text { when you } \\
\text { have an } \\
\text { infraction of } \\
\text { leaving traces, } \\
\text { it will be } \\
\text { indispensable } \\
\text { the } \\
\text { examination } \\
\text { of the body of } \\
\text { crime. }\end{array}$ & $\begin{array}{l}\text { It was } \\
\text { found that } \\
\text { giving } \\
\text { priority to } \\
\text { the } \\
\text { realization } \\
\text { of the body } \\
\text { of crime } \\
\text { when it } \\
\text { comes to } \\
\text { crime that } \\
\text { comes } \\
\text { involved. }\end{array}$ \\
\hline
\end{tabular}

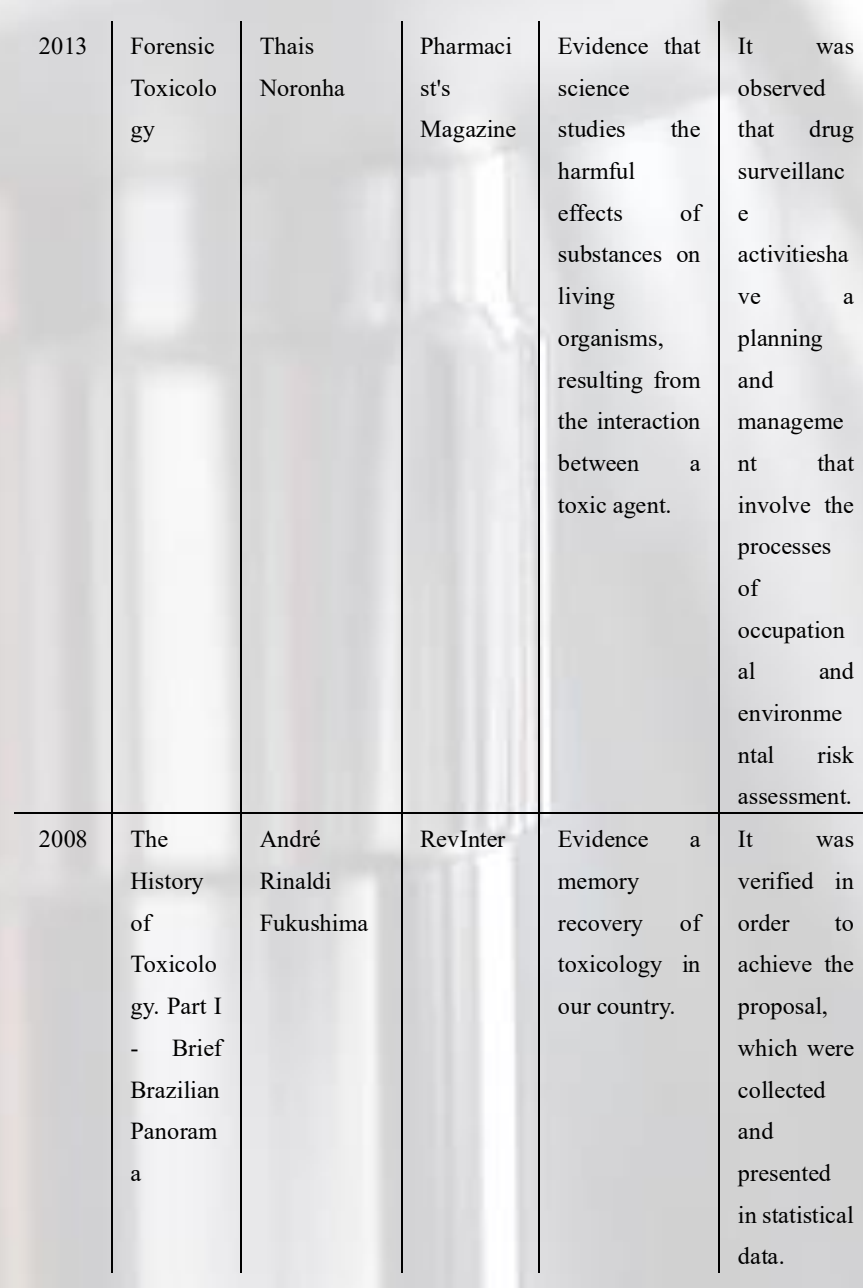

\section{Conclusion}

The area of criminal investigation presents numerous possibilities of actions, among them forensic toxicology, where experts identify the presence of substances in the bodies of people at the scene of crimes and accidents, assess the efficiency of firearms and perform the ballistic confrontation between weapons and ballistic projectiles, at the crime scene are also performed the identification of traces and objects related to the criminal act.

It is understood, therefore, that forensic science professionals should have continuous training, as well as guidance and ethical and legal training focused on the dilemmas and specific cases of their functions seeking to prevent biases and biases.

\section{References}

[1] AZEVEDO, F.A. FUKISHIMA, A.R. História da Toxicologia. Parte I - breve panorama brasileiro. Revista Intertox de Toxicologia, Risco Ambiental e Sociedade, v.1, p.2-32, 2008.

DOI: 
4 Lima, J.C.; Lima, A.F.P.S.; Silva, E.T.B.; Silva, E.B.; Lima, J.B.A.S.; Silva, M.C.; Silva, M.E.F.; Santiago, B.C.S.; Alves, T.E.S.;

Damacena, L.P.; Muniz, D.B.; Batista, E.A.; Gomes, A.D.; Santos, E.M.L.T.; Santos, C.J.; Paiva, M.I.S.; Álvares, E.B.S.O. The Performance of the Pharmacist in Forensic Toxicology and its Importance: Literature Review...

[2] NORONHA, THAIS. Toxicologia Forense. http://portal.crfsp.org.br/revista/294-revista-112/4629-

revista-do-farmaceutico-112-analises-clinicas.html

[3] BRASIL. Lei do Artigo 158 do Decreto Lei n 3.689 de 03 de Outubro de 1941. Rev. Jus Brasil 2019: https://www.jusbrasil.com.br/topicos/10666685/artigo158-do-decreto-lei-n-3689-de-03-de-outubro-de-1941

[4] CARNEIRO R, RCML 2020, p. 02 http://revistacml.com.br/

[5] BARROS, F; KUHNEN, B; SERRA, M.C; FERNANDES, C, M, S. Ciências forenses: Princípios éticos vieses. 2021: https://www.scielo.br/j/bioet/a/GYNrWJgbtfwQskD5TR $7 \mathrm{dCGN} /$

[6] SERRA, M.C; FERNANDES, C, M, S. BARROS, F; KUHNEN, B; Ciências forenses: Princípios éticos e vieses. 2021: https://www.scielo.br/j/bioet/a/GYNrWJgbtfwQskD5TR $7 \mathrm{dCGN} /$. 